\section{Reputation and financial reporting in Finnish public organizations}

Reputation in Finnish public organizations

\author{
Antti Rautiainen and Vilma Luoma-aho \\ School of Business and Economics, University of Jyväskylä, Jyväskylä, Finland
}

\begin{abstract}
Purpose - This article analyzes the links between financial reports and reputation in the context of Finnish public sector organizations. In general, the paper discusses the accounting treatment of intangible and tangible assets and the quality and relevance of public sector financial reporting.

Design/methodology/approach - For data, we combine three data sets: financial statement information of eight anonymous Finnish public organizations, the results of a reputation survey among their key stakeholders $(N=914)$ and a sample of the social media sentiment around the organizations.

Findings - Our findings suggest that a decrease in spending and, surprisingly in the nonprofit sector, an increase in the surplus, indicate better perceived financial performance. An increase in surplus is positively linked with the reputational factors, for example, trust. However, disclosing excessive amounts of information, for example, in financial reporting seems to contribute to negative discussions on social media.

Practical implications - We highlight the importance of managing intangibles, including those not recognized in the balance sheet, such as reputation. We present three propositions with potential managerial relevance.

Originality/value - Despite the considerable amount of financial information disclosed by public sector organizations, few studies have analyzed its relevance or connection to reputation. This first-of-a-kind paper combines intangible and tangible assets by analyzing how financial data and intangible reputation are linked in the public sector accounting context. Six reputational factors were discovered, and financial performance was found to correlate with trust in the public sector.
\end{abstract}

Keywords Reputation, Financial statements, Intangibles, Public sector, Social media, Accounting

Paper type Research paper

\section{Introduction}

Reputation is increasingly seen as a valuable intangible asset for organizations (Boon and Salomonsen, 2020). Nevertheless, the accounting treatment of such intangible assets is not at all straight forward (Lev, 2019). The accounting treatment difficulties are highlighted in the public sector where profit is not available as a measure of performance, and where excellence in customer experience is not necessarily the only ideal, but there can be considerations of equality and public interest (see Canel and Luoma-aho, 2019; Haustein et al., 2019; Luoma-aho, 2007; van Helden and Reichard, 2019; Wæraas and Byrkjeflot, 2012). An increased disclosure of intangible assets as such does not change the organization or its processes, but from the financial accounting perspective, the financial statements do not necessarily communicate the true and fair view (see Hines, 1988; Lev, 2019). This could challenge the relevance of financial reporting (Beisland and Hamberg, 2013), also because it is not known whether

(C) Antti Rautiainen and Vilma Luoma-aho. Published by Emerald Publishing Limited. This article is published under the Creative Commons Attribution (CC BY 4.0) licence. Anyone may reproduce, distribute, translate and create derivative works of this article (for both commercial and non-commercial purposes), subject to full attribution to the original publication and authors. The full terms of this licence may be seen at http://creativecommons.org/licences/by/4.0/legalcode

The authors would like to thank the two anonymous reviewers for their valuable comments. The authors also acknowledge the comments received for earlier drafts of this paper, for example, at the Corporate Communications International Conference 2019 in Los Angeles as well as for the comments received at the Accounting Research Seminar in Tampere in November 2019.
Received 24 October 2020 Revised 14 January 2021 17 March 2021

Accepted 19 March 2021 
JPBAFM 33,4 current financial reports reflect stakeholder perceptions of organizational performance or reputation in the public sector.

Therefore, this article analyzes financial information and intangible assets such as reputation in the public sector context, with a focus on financial accounting. Financial reporting in the public sector is detailed but questions have been asked about who the (end-) users of public sector financial reports are, whether such users even exist, and if current financial information - or its quality - reflects organizational performance and is seen as relevant to stakeholders (e.g. Haustein et al., 2019; van Helden and Reichard, 2019). Prior research suggests that there are several stakeholders that can be potential users of public sector financial statements, including politicians, citizens and media (van Helden and Reichard, 2019). Reputation provides an overall view of the stakeholders' attitudes and experiences by combining views from different stakeholders, and several subdimensions of reputation such as service and trust (Canel and Luoma-aho, 2019; Christensen and Gornitzka, 2019; Lev, 2019; Overman et al., 2019; Tyler, 2006).

Despite some potential value and relevance, many intangible assets (e.g. reputation, research expenses) are not recognized in balance sheets (see, e.g. Lev, 2019). Further, the public sector is an interesting financial reporting context because there are, by definition, no market values or profit measures available, and thus the relevance of intangibles or public sector financial reporting to stakeholders is uncertain. Further, there are currently many sources of performance information, such as social media (see, e.g. Overman et al., 2019), possibly challenging traditional financial statement disclosure (see, e.g. Alcaraz-Quiles et al., 2018). Even if both reputation and financial reporting in public organizations have been analyzed (see Boon and Salomonsen, 2020; Haustein et al., 2019; van Helden and Reichard, 2019), the possible links between financial statement information, reputation and perceptions of organizational performance (by key stakeholders and more generally in social media) remain in our view unstudied in accounting research.

Therefore, in order to bridge this gap in public sector financial accounting research, this paper analyzes if stakeholder perceptions about reputation and the financial reporting information are linked in the public sector. We do this by studying the links between the perceptions of key stakeholders (survey data, $N=914$ ), the views of the general public (through a sample of social media sentiment), and the financial statement information. Such links or relations might suggest that the financial information matters (i.e. they have relevance for stakeholders). We also analyze the nonrecognizable intangible assets, such as reputation, in the Finnish public sector financial reporting context. Further, we suggest a new categorization of intangible and tangible assets in the public sector and offer guidelines for developing public sector financial reporting.

Previous research on intangible assets suggests that organizations that are able to build intangible assets, including nonrecognizable assets such as reputation, brand value, social media impact or social capital can also increase their financial value in terms of tangible assets (Gu and Lev, 2011; Fombrun and Van Riel, 2003; Köhler and Hoffmann, 2018; Lev, 2019; Xun and Guo, 2017). However, intangible assets are subject to speculation and uncertainty (Hines, 1988; Lev, 2019) and much of the research combining intangibles and tangibles is conducted in the context of corporations and businesses, so little is known whether any link is apparent in the public sector (see Canel and Luoma-aho, 2019; Lev, 2019). Therefore, we analyze reputation and refine the categories of intangible and tangible assets in the public sector accounting context.

The tax-funded public sector in Finland is relatively large, warranting some public interest. Further, the public sector makes an interesting context for analyzing reputation and financial reporting information because of the qualitative goals, such as equality, democracy and regional policies, yet with no clear measure for success (e.g. Canel and Luoma-aho, 2019; 
Lapsley, 2008; Luoma-aho, 2007). Corporate reporting practices have been brought to the public sector, suggesting that there might be parties interested in these numbers and in the financial situation, although this so-called new public management trend with private sector accounting disclosure and practices does not always suit the conditions of the public sector (Lapsley, 2009).

Recently the use of social media and information technology has brought about changes in how we obtain organization-specific information (see Quattrone, 2016; Xun and Guo, 2017). Media attention may affect organizational perceptions (Johnsen et al., 2019), and especially the negative tone of social media discussion tends to have a link to decreasing performance and stock prices (Xun and Guo, 2017). However, in the public sector, the links between social media sentiment and performance may need to be assessed based on stakeholders' perceptions of performance, that is, through survey data like in this paper. Further, there is a growing research area regarding the quality and communication of financial performance in the public sector (e.g. Alcaraz-Quiles et al., 2018; Pina et al., 2009). However, it is not clear whether public sector financial disclosure is informative or relevant for assessing intangible issues such as reputation in the sense of reflecting stakeholder perceptions, especially during the current era of communicating through various channels such as social media. Thus we analyze whether the key stakeholder perceptions on the reputation and performance of public organizations are related to financial reporting information (including elements of reporting quality and information content) and also to social media perceptions. The following research question is guiding our research:

$R Q$. Are stakeholder perceptions of reputation linked to the financial accounting information disclosed in the financial statements of the case organizations?

We begin this paper with a theoretical discussion of reputation and other key concepts. Further, in order to improve understanding of the information disclosed (and not included) in financial statements, we discuss the general treatment of intangibles and tangibles in the public sector. In our empirical section, we use three datasets. For portraying stakeholder perceptions, we use a reputation survey of key stakeholders $(N=914)$ of eight Finnish case public sector organizations from 2018; further, the information from the 2016 and 2017 financial statements of the eight case organizations available on the Internet is analyzed, and, for comparison and validation purposes in our current digital era, a sample of social media discussions is used to grasp the perceptions of the general public. Next, we report the findings of our statistical analyses. Finally, we draw conclusions and present three propositions for future research.

\section{Reputation and financial performance}

In this paper, we study the relations between financial statements, reporting information and reputation. Conceptually, reputation belongs to intangibles that are realized through communication and can be regarded as nonmonetary assets that enable and give access to tangible assets (see Canel and Luoma-aho, 2019, p. 77). Corporate reputation can be defined as a record of past deeds, or how the organization is perceived by its stakeholders (Carroll, 2016; Dowling, 2016). Reputation consists of different dimensions (e.g. performance, technical, moral and procedural), perspectives (e.g. instrumental, cultural and symbolic) and characteristics, such as credibility, reliability, responsibility and trustworthiness (Christensen and Gornitzka, 2019; Lange et al., 2011; Fombrun, 1996). Reputation is related to deeds, whereas image refers to impressions (Luoma-aho, 2008). Reputation is also a record of trustworthy or untrustworthy behavior (Sztompka, 2000; Rousseau et al., 1998, p. 397;
Reputation in Finnish public organizations 
JPBAFM 33,4
Wallin Andreassen, 1994), occurring in a social context where stakeholders and the organizational actors interact.

Stakeholder views contribute to organizational legitimacy, which typically relates to adding value and conforming to societal expectations (see Meyer and Scott, 1983; Rautiainen et al., 2017; Tyler, 2006). Reputation can contribute to organizational stability, profit and employee loyalty (Bromley, 2002; Fombrun and Van Riel, 2003; Lange et al., 2011). These appear as attractive attributes also to public sector organizations struggling with financial and political pressures. However, public organizations typically do not pursue profit and they do not necessarily need to worry about short-term liquidity or effectiveness because they often have defined, mandatory tasks and a legal status as a government funded organization (Canel and Luoma-aho, 2019; Crawford et al., 2018).

Reputation may change with stakeholder opinions and expectations, and is affected by changes in technology, the environment and professional expertise (Barton, 2005; Jensen and Roy, 2008; Suddaby et al., 2015). Public organizations are surrounded by "a host of social elements" including public servants, voters, professionals and interest groups, and this multiplicity of interests causes conflicting views on legitimacy and prioritization (Meyer 1996, p. 244; Meyer and Scott, 1983, pp. 201-211). Reputation is widely studied in communications research, in organizations research and in political science (see Boon and Salomonsen, 2020; Wæraas and Byrkjeflot, 2012), but in the field of public sector accounting, studies of reputation are still scarce. Previous studies in the Finnish public sector context suggest that public sector reputation includes specific factors with differing emphases: authority, esteem, trust, service and efficiency (see Luoma-aho, 2008; Luoma-aho and Mäkikangas, 2014). Compared to privately owned companies, a short-term financial result is not the main focus in the public sector (e.g. Lapsley, 2008). The stable and open Nordic public sector offers an interesting context for considering how organizations manage stakeholder expectations and reputation so that information is easily available (see Luoma-aho and Mäkikangas, 2014; Olkkonen and Luoma-aho, 2015; Wæraas, 2014). Furthermore, the relevance of public financial reporting seems to deserve further study (see Christensen and Gornitzka, 2019; Haustein et al., 2019; Lapsley, 2008; Meyer and Scott, 1983). It hence remains unclear how reputation and financial reporting items intertwine in the eyes of public sector stakeholders. Without a profit target, there might not be links between reputation and financial performance, that is, whether financial disclosure holds explanatory power in explaining reputation.

Our analysis starts with the tangible financial reports. These are compared with the intangible stakeholder reputation survey data and a sample of social media discussions in 2018 related to the organizations under study in order to get a general public perspective on reputation. This is also expected to offer views on the use and usefulness of financial reports by various potential users of financial information. In addition, the reputational factors suggested by Luoma-aho (2008), authority, esteem, trust, service and efficiency, will be re-examined with current data.

\section{Intangibles and performance information disclosed in accounting reports}

Reputation and other intangible assets may drive performance and shape the market evaluations and the profit of organizations (Laskin, 2018; Lev, 2019), even when the valuerelevance of accounting profit alone for intangible-intensive companies has been questioned in the corporate sector (Lev, 2019). The analysis of public sector performance faces several additional difficulties due to the lack of profit measurement and of paying customers (Lapsley, 2008; Canel and Luoma-aho, 2019). There is financial reporting in the public sector but analyses of public sector performance often involve proxy or noncomparable measures of short-term efficiency (Kihn, 2010; Rautiainen et al., 2017). Moreover, it is not always clear who the users of financial statements are and what their role is in accounting developments 
(Haustein et al., 2019; Stenka and Jaworska, 2019). Yet, there are potential user groups for public sector financial statements, including key stakeholders such as employees, creditors and politicians as well as more generally citizens and media (van Helden and Reichard, 2019).

Currently, reputation and other intangibles are increasingly seen as drivers of performance and value both in the private and public sectors, and there is a growing interest in measuring and reporting them properly (see Christensen and Gornitzka, 2019; Lev, 2019; Overman et al., 2019). It has been suggested that a positive reputation among stakeholders can be an intangible asset that may provide the organization with competitive advantage and protection during crises (Canel and Luoma-aho, 2019), although there can also be reputation risks stemming from citizen experiences (Canel and Luoma-aho, 2019).

Accounting reports might first appear as relatively objective and tangible, though the numbers may be flawed or intended for some specific use (Ahrens and Chapman, 2007; Lev, 2019). Already Hines (1988) noted that the valuation principles and the methods of communicating accounting information affect the "reality" conveyed. Nonetheless, organizational members may know the limitations of accounting practices, allowing coordination and communication through the information (Ahrens and Chapman, 2007; Quattrone, 2016). Further, media attention may be important regarding several goals of public organizations, while social media offers new ways for informing various stakeholders (Canel and Luoma-aho, 2019; Johnsen et al., 2019; Laskin, 2018; Luoma-aho, 2015).

\section{Accounting treatment of intangibles}

The division between intangibles and tangibles is not always very clear because assets (both intangible and tangible) can be considered as measurable streams of future benefits controlled by an entity (Power, 2001). In financial accounting, the International Accounting Standard (IAS) 38.8 states that "an asset is a resource controlled by the entity as a result of past events from which future benefits are expected to flow to the entity". Further, an intangible asset is an identifiable nonmonetary asset without physical substance (Power, 2001). Reputation, however, is not considered as an asset in accounting terms at all as it is not controlled by the entity (especially in case of bad reputation), and the future benefits are unlikely, making the item both risky and sometimes more of a liability than an asset. Yet, as noted in the previous section, the potential of reputation as an asset (in supporting brand name, etc.) is obvious.

We next summarize the accounting treatment of intangibles and tangibles and, for illustrative purposes, consider the asset categories as a continuum, ranging from intangible and nonrecognizable assets (potential assets not recognized in the balance sheet) to tangible and recognizable assets (recognized in the balance sheet). The intangible nonrecognizable assets include several intangibles that are typically studied in communications research, such as human capital, image and reputation (Canel and Luoma-aho, 2019; Cinca et al., 2003). From an accounting perspective, intangible nonrecognizable assets are uncertain but can hold potential for value, although some might occasionally be even regarded as liabilities. The asset nature of some intangibles, such as goodwill and development costs, is so identifiable that they need to be recognized as intangible assets (IFRS 3; Lev, 2019). Then, continuing our categorization towards tangible assets, there can be contingent tangible assets (IAS 37.10), biological assets (IAS 41.5), deferred tax assets (IAS 12.5), and derivatives (IFRS 9), and finally there are the highly probable (IFRS 5.A) or the certain tangible assets (through, e.g. commitments, collaterals or guarantees, see IFRS 9). However, even under the going concern assumption, some uncertainty about future economic benefits is typically related to both intangible and tangible assets (e.g. Barth, 1994; Barth and Landsman, 1995).

In the public sector, the future economic benefits are often even more unlikely or at least uncertain. However, as with private sector companies, some intangible assets such as computer software may serve the organization for several years, that is, hold service 
JPBAFM 33,4 potential. According to the International Public Sector Accounting Standard 31 (IPSAS 31, para 16), "an intangible asset is an identifiable non-monetary asset without physical substance". Further, an asset is required to be identifiable, with control over the resource together with reasonable expectation of future economic benefit or service potential, the fair value of which needs to be measurable (para 18 and 28). Identifiability means that either the asset is "separable", that is, can be separated or "divided from the entity and sold, transferred, licensed, rented, or exchanged" or it "arises from binding arrangements" (para 19).

As an answer to the uncertainty of economic benefits in the not-for-profit sector, IPSAS 31 (para 12) also approves intangible assets described as "intangible heritage assets" with "cultural, environmental, or historical significance". Examples of intangible heritage assets include recordings of significant historical events and the rights to use the likeness of a significant public person on postage stamps or coins. This is possible even if clear market prices or clearly estimable useful lives did not exist for the assets (IPSAS 31.12). Additionally, comparably to IAS 38, the recognition of development costs as an asset is possible under IPSAS 31.55 if technical feasibility and probable future economic benefits exist. Thus, our categorization of the continuum of intangible and tangible assets in the public sector context includes the following four categories (from the least recognizable to the most recognizable):

(1) Intangible nonrecognizable assets (with varying likelihood of economic potential, including human capital, brands, image and reputation (see e.g. Cinca et al., 2003);

(2) Intangible heritage assets (recognizable for some public organizations under IPSAS $31)$;

(3) Recognizable intangible assets (e.g. development, licenses and rights, see Lev, 2019);

(4) Tangible (and recognizable) assets (with varying potential for future economic benefits).

The first three categories involve intangibles, and can be partly overlapping concerning internally created brands and heritage assets (like pictures of iconic products), where a demarcation may need to be made on a case by case basis. The three intangible asset categories typically involve more uncertainty than tangible assets, even if tangible assets too involve subclasses, managerial discretion and uncertainty in recognition and valuation (see Barth and Clinch, 1998; Hines, 1988).

Some nonrecognizable assets, like internally created brands, may be relevant and sustainable (long-term, i.e. going concern earnings components, see Beisland and Hamberg, 2013), whereas others might be short-term. Moreover, the benefits obtained are not necessarily just economic but there can be probable environmental and societal benefits, increasing for example the appeal of an area as a place of residence (Kihn, 2010; Källström, 2019). Nevertheless, all assets (intangibles and tangibles, recognizable and unrecognizable) with some likelihood for high economic potential (or risk, see Power, 2000) might be seen as strategic and potentially value-relevant, thus requiring managerial and investor attention (see Cordery and Hay, 2019; Lev, 2019), perhaps also some (voluntary) accounting disclosure.

Ways of considering the economic value of intangibles for business enterprises include market values (e.g. licensing cost or goodwill as the excess purchase price over the fair value of purchased assets, see IFRS 3; Lev, 2019) and the valuing of any identifiable component of complex intangibles (Cinca et al., 2003). Further, if there are known intangibles in listed companies, such values might be scaled to the size of a similar unlisted organization (Lie and Lie, 2002). Market values are not very applicable, however, to nonprofit organizations, and the impact of intangibles on quality and other objectives might be estimated only roughly (Cinca et al., 2003). Managers might for example assess whether the expected effect of intangibles is positive or negative. Expected qualitative impacts might be considered in terms of 
probability and class, such as environmental or reputational benefits (or risks, see Jordan et al., 2013; Lev, 2019; Power, 2000).

\section{Public sector reporting}

Unlike listed companies, public sector reporting is typically not strictly guided by international, for example, EU-level regulation. It has been suggested that a lack of comparable financial disclosure leads to growing importance for audits and performance audits in the public sector, even though these are noncore activities (Olson et al., 2001; Power, 2000). However, there have been advances in trying to improve the comparability of public sector financial reporting and management through private sector practices (new public management(NPM), see, e.g. Lapsley, 2008) and applying accounting standards also for the public sector (IPSAS, see, e.g. Christiaens et al., 2015). In public sector financial reporting research, Alcaraz-Quiles et al. (2018, p. 297; see also Pina et al., 2009) note that the transparency and quality of accounting communication can be judged based on the items disclosed, accessibility (time it takes to find information) and usability. Pina et al. (2009), for example, analyze the qualities of public sector web page information including voluntary disclosure such as glossaries and FAQ sections.

In this study, we analyze the financial reporting of the eight case public organizations, for example, financial statements and other key information publicly available on the Internet from years 2016 and 2017. After a restructuring, one case organization did not disclose comparable information on its web pages regarding the year 2017. Therefore, the quality of reports was difficult to compare or assess based on the disclosed information, but some reporting items or dimensions, such as surplus changes, were analyzable. The analysis of intangibles is based on stakeholder perceptions, particularly in the survey of the key stakeholders of the case companies.

As discussed above, financial statement analysis, especially regarding the division between tangibles and intangibles in the public sector, is not simple but many accounting items are subject to uncertainty and speculation (Hines, 1988; Canel and Luoma-aho, 2019; Lev, 2019). Instead the role and relevance of intangibles and accounting reports seems to require further analysis. However, the connections between perceptions (reputation, social media sentiment) and accounting numbers (e.g. surplus change) are expected to be nonexistent or weak in the public sector context. Yet, good governance in the public sector might relate to both reputation and the quality of accounting information, which currently includes more and more aspects from private sector reporting (e.g. Lapsley, 2008; Suddaby et al., 2015). It is interesting therefore to find out whether there are links between reputation and financial figures in the public sector, and the Finnish context also offers a "laboratory" environment to study the social media sentiments, as the Finnish language area is relatively concise, suggesting that even if the sample is fairly small, it may involve less spam. Next, we present our data and methods.

\section{Data and methods}

Three connected datasets were used in this study: the stakeholder reputation survey, the social media sentiment sample (taken from the $M$-adaptive program for comparison, including sentiment judged positive or negative by the program), and the financial reports of eight anonymous Finnish case organizations that were publicly available on the Internet. These are summarized in Table 1.

\section{Dataset 1: key stakeholder perceptions}

A quantitative survey of stakeholder assessments $(N=914)$ on reputation was carried out related to eight public organizations from the field of one Finnish ministry and seven other
Reputation in Finnish public organizations 
JPBAFM 33,4

\begin{tabular}{|c|c|c|c|}
\hline & $\begin{array}{l}\text { Dataset 1: } \\
\text { stakeholder } \\
\text { reputation survey }\end{array}$ & $\begin{array}{l}\text { Dataset 2: social media } \\
\text { sentiment sample }\end{array}$ & Dataset 3: the financial reports \\
\hline $\begin{array}{l}\text { Documents } \\
\text { used }\end{array}$ & $\begin{array}{l}\text { The survey } \\
\text { instrument based on } \\
\text { Luoma-aho (2008) }\end{array}$ & $\begin{array}{l}\text { Internet documents in Finnish } \\
\text { from Blogit, Facebook, Google } \\
\text { Plus, Instagram, News, news } \\
\text { forums, Reddit, Tumblr, } \\
\text { Twitter, VKontakte and } \\
\text { Youtube }\end{array}$ & $\begin{array}{l}\text { The } 2016 \text { and } 2017 \text { financial } \\
\text { statements of the eight case } \\
\text { organizations (analyzed in the } \\
\text { datasets } 1 \text { and 2) }\end{array}$ \\
\hline $\begin{array}{l}\text { Number of } \\
\text { responses/ } \\
\text { documents }\end{array}$ & $\begin{array}{l}914 \text { frequent } \\
\text { stakeholders of the } \\
\text { case organizations }\end{array}$ & $\begin{array}{l}\text { Average of } 16,710 \text { social media } \\
\text { feeds per case organization } \\
\text { from the M-Adaptive program, } \\
\text { July to Dec } 2018 \text { (except one } \\
\text { organization Sept to Dec for } \\
\text { technical reasons) }\end{array}$ & $\begin{array}{l}15 \text { comparative annual reports } \\
\text { (one organization merged so one } \\
2017 \text { financial statement was } \\
\text { not available) }\end{array}$ \\
\hline $\begin{array}{l}\text { Type of } \\
\text { analysis/ } \\
\text { methods }\end{array}$ & $\begin{array}{l}\text { Statistical analysis, } \\
\text { e.g. principal axis } \\
\text { factoring (PAF) }\end{array}$ & $\begin{array}{l}\text { The percent proportion of } \\
\text { positive and negative feeds out } \\
\text { of the total taken as variables } \\
\text { SocMedPos and SocMedNeg, } \\
\text { based on the M-Adaptive } \\
\text { program algorithm }\end{array}$ & $\begin{array}{l}\text { Financial ratios and a subjective } \\
\text { grading of reporting content } \\
\text { and accessibility, scale } 2-10\end{array}$ \\
\hline
\end{tabular}

related organizations in 2018. The organizations represented four sectors: research, authority functions, semicommercial functions and legislation. The response rate was $33 \%$. Survey data $(N=914)$ were analyzed in SPSS, with correlation, regression and factor analyses (see Appendixes 1-6) to form reputational factors for these public sector organizations. Then we analyzed the links between reputation and reporting (both correlations and regressions). In the Finnish public sector context, a reputation survey has been conducted by Luoma-aho (2008) and to allow comparable results we use the same survey questionnaire instrument and the same sector (i.e. same case organizations) when we measure reputation among the key Finnish stakeholders. We can for example see if the five public sector reputational factors noted by Luoma-aho (2008) can still be found in our newer data (for the questionnaire, see Appendix 5). Our survey was sent to the most important stakeholders of the organizations, such as employees, customers, collaborative organizations and political and administrative decision-makers. Only stakeholders who had frequent dealings (varying from daily interaction to annual contacts) with the organizations were chosen, because many of the organizations' products and services are not necessarily very well-known beyond these key stakeholders.

\section{Dataset 2: other stakeholder perceptions}

We analyzed social media sentiment related to the organizations under the study. This gives a general view of the public sentiment. Further, we see the Finnish context as a benefit as it avoids many mixed results compared to the possibilities for data confusion more globally. Our Finnish language social media data sample was taken from the M-Adaptive system by M-Brain during the latter half of 2018, and the relative proportions of positive or negative feeds (as judged by the program parameters) were considered as variables. The social media sample serves as data for comparison in order to ascertain whether the views presented by the stakeholders in the survey reflect general views presented in social media.

\section{Dataset 3: financial information}

Alcaraz-Quiles et al. (2018, p. 297; also Pina et al., 2009) note that transparency and the level of information disclosure can be assessed based on the items disclosed, accessibility (the time it 
takes to find information) and usability, which means the qualities of the web page analyzed, including additional languages, glossaries and FAQ sections. However this time the qualities of the web page were not considered important, so our analyzed dimensions of reporting were accessibility as well as financial information (surplus, etc.) and information content, with a subjective scale of $2-10$. This grade was then used as a variable in the statistical analyses conducted. The available 2016 and 2017 financial reporting data of the public organizations related to datasets 1 and 2 were analyzed and coded according to the following:

(1) Information disclosed about effectiveness etc. in online reports:

Reputation in Finnish public organizations

The scale was 1-7: 1st point: availability of statement for financial performance (similar to profit/loss statement); 2nd point: availability of balance sheet; 3rd point: reporting of expenses; 4th point: reporting of lines of operations; 5th point: reporting of key figures; 6 th point: reporting of financial ratios and performance indicators and 7th point: fully comparable and transparent information disclosed.

(2) Accessibility of the online information:

The evaluated criteria included time spent searching and difficulty of finding, and the scale was $1-3$, where 1 is difficult (more than 1 minute), 2 moderate (more than 30 seconds) and 3 easy to find (less than 30 seconds).

To portray the financial information, financial ratios (see, e.g. Gu and Lev, 2011) were used as variables: the amount of total assets (average of 2016 and 2017), surplus for 2016 and 2017 (and their change percent and average) and the change in total spending (from 2016 to 2017). However, one of the organizations changed its organizational structure and name, so the change in figures could not be calculated reliably, so no change was reported regarding that one organization. Further, with eight focus organizations, the organizational variables are not normally distributed in spite of the otherwise relatively fair sample size considering the size of the Finnish context. However this case analysis provides information about the case organizations of the stakeholder survey.

We used statistical multivariate methods, such as regression and factor analyses in SPSS 24 , in order to find out if the survey item "general grade of operations" is linked to other data items. The general grade of operations serves as an overall measure of the level of performance and is the main dependent variable of this research. The independent variables include reputation survey items, social media sentiment and financial figures (see Table 1 and Appendices).

\section{Empirical results}

Reputation of public sector organizations and stakeholder perceptions

When analyzing the data with regression analysis, our key performance indicator (the dependent variable in our explanatory model) was the general grade for operations, measured as "overall school grade", as in elementary schools in Finland there is a grading scale of 4-10 (where 10 is the best grade). We consider that the general grade indicates overall performance and reputation of the organization. The most important explanatory variables (the qualities driving a perception of an organization with high reputation) included: meeting expectations, being cooperative, having high quality, being fast and acting for the common good of society ( $R$ Square was 0.726 , see Appendix 1 ). However, interestingly for our comparison purposes, the general social media sentiment did not agree with a high grade given by key stakeholders (Appendix 2).

Further, the reputation survey results show that the reputations of the case organizations were considered quite good and stable among the stakeholders. On a scale of $4-10$, the average was 8.25 , and all averages of the $1-5$ scale fell between 2.8 and 4.8 . Using explorative 
JPBAFM 33,4

496 factor analysis with principal axis factoring (PAF) and with promax rotation (allowing a simple structure and oblique rotation where factors may correlate, see Finch, 2006), we found six reputational factors (instead of the five suggested by Luoma-aho, 2008). We named these factors as follows (see Appendixes 4 and 5):

(1) trust;

(2) authority;

(3) efficiency;

(4) esteem;

(5) well-known service;

(6) easy to reach service

Compared with the study of Luoma-aho (2008) that suggested five factors in the Finnish context, we note that trust remains the factor with the most explanatory power. The trust factor also included ethical elements (see Appendix 4). Further, in addition to minor changes in factor loadings, factor strengths and variable groupings, we see that the service factor found by Luoma-aho (2008) can now be separated into two areas: (1) being well-known and meeting expectations as well as (2) being easy to reach with a clear contact person.

To complement our stakeholder view, a social media analysis was conducted using the organization names as search phrases and the results as sentiment data (taken from the $M$-Adaptive social media monitor in Finnish). It was found that the general grade of performance correlated positively with negative sentiment $(0.174, p<0.001, N=900)$ and that increase in spending was negatively associated with improvements in the general grade $(-0.073, p<0.05, N=900$, Appendix 2). These results suggest that the (key) stakeholder views and the views of the general public are not necessarily aligned because public authorities have legislative tasks that are not necessarily intended to just please the public. Further, more spending may seem a waste of resources. However, being a modern and open authority (i.e. factor 2) positively correlated with both positive and negative feeds (and thus had fewer neutral feeds). Moreover, the higher the reporting quality was (as suggested by easy access and informative content), the more negative were the views on that organization (i.e. the lower the proportion of positive social media feeds out of the total feeds). This suggests that detailed and accessible reporting seems to increase the possibilities for negative discussions in social media (see Appendix 6).

\section{Quality of financial information}

Some of the available financial statement data were not fully comparable. For example, information about effectiveness, or the number of services given, were not reported systematically due to the different nature of the case organizations and their services. Therefore, following the guidelines set in Alcaraz-Quiles et al. (2018) and Pina et al. (2009), an estimation of the quality of financial information was used. We used a grading from 2 to 10 in the reporting quality scoring model (Table 2). Information in financial reports for both 2016 and 2017 was graded and then the average was used as a proxy variable for reporting quality.

As can be seen from the second column of Table 2, none of the organizations received a full 7 for comparable performance information but four organizations received grade 6 for having made a good attempt at disclosing what they had done during the year. Second, the accessibility of the information (ease of finding and using) was analyzed with a grading from 1 to 3. For example, the information of one organization was so difficult to find from the Internet that it received the lowest score of one, whereas five organizations received the highest score of 3 . 
We then used the total score of reporting quality proxy (from Table 2, with a scale from 2 to 10) as a variable as an addition to the organization-specific survey responses. A large total amount of assets positively correlated with responses highlighting the authority factor (Appendix 6), suggesting that the size of an organization was an indication of being bureaucratic in reporting, for example. In our regression analysis, the large size of the organization (based on the balance sheet) and a high surplus percent suggests lower grade for the quality of reporting, suggesting that bigger resources, assumedly also for high-quality reporting, do not necessarily guarantee informative and easy-to-find information (see Appendix 4).

A high surplus percent in general suggested being less esteemed, perhaps with the idea that not everything was done that could have been to serve the interests of the public. A positive change in the surplus margin, however, suggested that the organization was being seen as more ethical, more effective, more esteemed and easier to reach. Further, contrary to expectations, there seems to be a relation between disclosure, social media communication and reputation. Also, based on correlations, less spending than before seems to be considered an improvement and a positive thing, possibly considered as an indication of proper control over expenditure. This was our finding even if there is no evidence whether the improvements in the surplus margin were based on more effectiveness or, for example, just less service. Further, even relatively minor changes in surplus might be considered reputable - or be communicated as success stories.

Finally, we looked at the school grade with regression analysis (Appendix 7), where we used the factors as well as surplus percent change, spending percent change, social media negative views and reporting quality proxy as our independent variables. Here, we can see that surplus percent change and reporting items are positive indicators of reputation. However, the spending percent change now, together with other variables, appears as a positive indicator suggesting that bigger organizations might be more reputable. Social media negative views were nonsignificant (see Appendix 7).

\section{Discussion and conclusions}

This paper was the first attempt, as far as we know, to categorize intangibles and tangibles and to empirically research how tangible and intangible assets are linked in the context of public sector accounting. Initially, the financial accounting information was expected not to have much connection to reputation because intangible assets are not disclosed in financial statements (e.g. Lev, 2019). Further, the level of performance among different public sector organizations is difficult to judge, and the quality and comparability of performance or reporting can be problematic to measure (see, e.g. Alcaraz-Quiles et al., 2018; Canel and Luomaaho, 2019; Haustein et al., 2019; Luoma-aho, 2007; Pina et al., 2009; Rautiainen et al., 2017;

\begin{tabular}{lccc}
\hline & $\begin{array}{c}\text { Information about organizational } \\
\text { effectiveness (availability of cost } \\
\text { effectiveness data) }\end{array}$ & $\begin{array}{c}\text { Accessibility of information (time spent } \\
\text { searching, difficulty of finding: 1: } \\
\text { difficult, 2: moderate, 3: easy) }\end{array}$ & $\begin{array}{c}\text { Total score } \\
\text { (from 2 to }\end{array}$ \\
\hline 1 & 4.5 & 2 & 10 ) \\
\hline 2 & 6 & 3 & 6.5 \\
3 & 6 & 3 & 9 \\
4 & 5 & 3 & 8 \\
5 & 6 & 2.5 & 8.5 \\
6 & 6 & 3 & 9 \\
8 & 2.5 & 1.5 & 4 \\
8 & 5.5 & 3 & 8.5
\end{tabular}

Reputation in Finnish public organizations 
JPBAFM 33,4

498 van Helden and Reichard, 2019; Wæraas, 2014; Wæraas and Byrkjeflot, 2012). No uniform reporting style about intangibles was observed even if all our case organizations reported performance data.

Our analysis of datasets 1 and 3 (the survey and financial statements), yielded a negative correlation between the authority factor and financial reporting variables, perhaps suggesting that extensive reporting is perceived as bureaucratic and static. We found that a positive change in the surplus margin correlates with the organization being perceived as more ethical, effective, esteemed and easier to reach. Further, less operating expenditure (negative spending change) suggests positive change in the general grade (correlation $-0.073, p<0.05$, see Appendix 2), although in our regression model (Appendix 7) this relation did not appear. The regression analysis however confirms that reputation and financial figures and reporting are positively linked (Appendix 7). Thus, even without a profit-maximization objective, financial information seems to be linked to the reputation in the public sector (suggesting relevance, in line with private sector results by Gu and Lev, 2011; Fombrun and Van Riel, 2003; and Köhler and Hoffmann, 2018). Our findings indicate that financial figures, such as more surplus, can support stakeholder expectations of control over spending and can be seen as an improvement even if in the public sector surplus is not necessarily a sign of improvement in the performance in terms of benefits to society (see Lapsley, 2008, 2009).

We noted that high information content in accounting reports did not correlate with trust and correlated negatively with authority, perhaps suggesting that extensive, high quality accounting reporting can be judged as bureaucratic or outdated reliance on financial data only, instead of other qualitative performance issues and reputation. Indeed, by using social media sentiment analysis for comparison and validation purposes (dataset 2), we noted that extensive accounting reporting seemed to be associated with more criticism of the organizations, suggesting not only bureaucratic practices but also that information might be used more against the public organization than in its favor among social media users, especially because good performance among the public organizations cannot really be objectively judged. Moreover, as our main contribution from dataset 1 (stakeholder survey, $N=914$ ), we found six reputational factors in the Finnish context (as compared to five in Luoma-aho, 2008), so in the current digital environment, two new factors can be separated regarding public sector reputation: being well-known and being easy to reach.

Considering reputation, financial reporting and reporting quality, we suggest the following propositions (propositions 1-3, P1-P3):

P1. Financial performance, reporting quality and reputation are linked in the public sector.

This relation and the importance of communication related to financial information (e.g. Hines, 1988), suggest that in the public sector the intangible nature of accounting is highlighted. Further, according to our results there seems to be some relevance in the surplus and its changes:

P2. Accounting surplus (or deficit) and their changes are linked to tangible and intangible properties, such as trust, in the not-for-profit sector.

The partly intangible nature of accounting profit is known (Hines, 1988), but this seems to apply to surplus as well. Further, according to our mixed results related to spending changes in the public sector, there might be an "area" of surplus or deficit that is considered to be appropriate in the operating circumstances. In such a "range of reasonability" or "corridor of compliance" the spending (or surplus or deficit) indicates neither excess spending nor potentially unequal practices.

Further, we contribute to earlier public sector research by suggesting a refined categorization of intangible and tangible assets according to their level of tangibility and 
accounting treatment. Intangible assets include forms of intellectual assets like the human capital of image (e.g. Cinca et al., 2003). We noted that even if all of such intangibles do not meet the criteria for accounting recognition, they can involve strategic importance (e.g. high potential benefits or risks, see Power, 2000), and thus require some additional voluntary financial statement disclosure. Any asset category may require managerial attention and affect the future success of organizations (see Lev, 2019), and so disclosure of significant items might give a better view on the organization. Our suggested categories, for analytical purposes, in the continuum of intangibles and tangibles in the public sector financial reporting are: intangible nonrecognizable assets, intangible heritage assets (see, e.g. IPSAS 31), other recognizable intangible assets (e.g. development costs, licenses and rights, see Lev, 2019) and tangible assets. Yet, all asset categories can include uncertainty related to the expected future economic, environmental and social benefits to stakeholders (see Barth and Clinch, 1998; Cordery and Hay, 2019; Beisland and Hamberg, 2013; Lev, 2019).

We highlight the potential of intangibles in the public sector (as Lev, 2019 does in the corporate context), and as a managerial implication, we suggest assessing the relevance, expected impact and probability of intangibles. By analyzing the risks and benefits involved, managers might be able to affect the likelihood and the impacts. Further, echoing the views of Lapsley (2008) and Johnsen et al. (2019), we expect performance audits to receive more attention in the public sector because many intangibles are not recognized. This may however lead to effort being expended in audits instead of in core operations (Olson et al., 2001). Further, it seems that not only the managers but also the key stakeholders can see the functionality and meanings in accounting communication, even if other users such as the general public do not (Ahrens and Chapman, 2007; Haustein et al., 2019; Stenka and Jaworska, 2019; van Helden and Reichard, 2019). The perceptions of performance and reputation come from many sources, so consistent (voluntary) financial reporting practices, such as disclosure of additional information (in financial statement notes) about the potential and the risks related to the key intangible assets of the organization might be helpful. Further, the current categorizations of assets and the comparability of reporting might not be perceived as sufficient in allowing an understanding of the organization's success (see also Quattrone, 2016), and so we propose that increasingly

\section{P3. Additional performance audits and voluntary disclosure are expected by stakeholders.}

Such performance audits may be needed to understand the value of nonrecognized intangibles, though they signal the rise of an audit society and risk management (Power, 2000).

As a pioneering study in this area, the paper has some limitations, including the small amount of financial data of the case reports, and possible challenges in analyses of quality, social media and in the comparability of cases. We assume that the Finnish organizational and cultural context is fairly comparable at the European level, but we call for broader data and new combinations of performance and perceptions data. Further, we encourage analysis of the propositions made, the relevance of assets to stakeholder groups and the ways in which different public sector organizations create, convey and use information about positive and negative sentiments. Finally, we call for research generally on reporting quality and on assessing public sector performance and effectiveness related to intangibles and their risks.

\section{References}

Ahrens, T. and Chapman, C. (2007), "Management accounting as practice”, Accounting, Organizations and Society, Vol. 32 Nos 1-2, pp. 1-27.
Reputation in Finnish public organizations 
JPBAFM 33,4

Alcaraz-Quiles, F., Urquia-Grande, E., Muñoz-Colomina, C. and Rautiainen, A. (2018), "E-government implementation: transparency, accessibility and usability of government websites", in AlcaideMunoz, L. and Rodriguez-Bolivar, M. (Eds), International E-Government Development, Palgrave Macmillan, pp. 291-306.

Barth, M. (1994), "Fair value accounting: evidence from investment securities and the market valuation of banks", The Accounting Review, Vol. 60 No. 1, pp. 1-25.

Barth, M. and Clinch, G. (1998), "Revalued financial, tangible, and intangible assets: associations with share prices and non-market-based value estimates", Journal of Accounting Research, Vol. 36, pp. 199-233.

Barth, M. and Landsman, W. (1995), "Fundamental issues related to using fair value accounting for financial reporting", Accounting Horizons, Vol. 9 No. 4, p. 97.

Barton, J. (2005), "Who cares about auditor reputation?”, Contemporary Accounting Research, Vol. 22 No. 3, pp. 549-586.

Beisland, L. and Hamberg, M. (2013), "Earnings sustainability, economic conditions and the value relevance of accounting information", Scandinavian Journal of Management, Vol. 29 No. 3, pp. 314-324.

Boon, J. and Salomonsen, H.H. (2020), "Public sector organizations and reputation”, in Luoma-aho, V. and Canel, M.-J. (Eds), The Handbook of Public Sector Communication, Wiley, pp. 215-227.

Bromley, D. (2002), "Comparing corporate reputations: league tables, quotients, benchmarks, or case studies?”, Corporate Reputation Review, Vol. 5, pp. 35-50.

Canel, M.-J. and Luoma-aho, V. (2019), Public Sector Communication: Closing Gaps between Citizens and Public Organizations, Wiley Blackwell, New York.

Carroll, C. (Ed.) (2016), The SAGE Encyclopedia of Corporate Reputation, SAGE, Thousand Oaks, CA.

Christensen, T. and Gornitzka, A. (2019), "Reputation management in the public agencies: the relevance of time, sector, audience and tasks", Administration and Society, Vol. 51 No. 6, pp. 885-914.

Christiaens, J., Vanhee, C., Manes-Rossi, F., Aversano, N. and Van Cauwenberge, P. (2015), "The effect of IPSAS on reforming governmental financial reporting: an international comparison", International Review of Administrative Sciences, Vol. 81 No. 1, pp. 158-177.

Cinca, C., Molinero, C. and Queiroz, A. (2003), "The measurement of intangible assets in public sector using scaling techniques", Journal of Intellectual Capital, Vol. 4 No. 2, pp. 249-275.

Cordery, C.J. and Hay, D. (2019), "Supreme audit institutions and public value: demonstrating relevance", Financial Accountability and Management, Vol. 35 No. 2, pp. 128-142.

Crawford, L., Morgan, G. and Cordery, C. (2018), “Accountability and not-for-profit organizations: implications for developing international financial reporting standards", Financial Accountability and Management, Vol. 34, pp. 181-205.

Dowling, G. (2016), "Defining and measuring corporate reputations", European Management Review, Vol. 13 No. 3, pp. 207-223.

Finch, H. (2006), "Comparison of the performance of varimax and promax rotations: factor structure recovery for dichotomous items", Journal of Educational Measurement, Vol. 43 No. 1, pp. 39-52.

Fombrun, C. (1996), Reputation, Harvard Business School Press, Boston.

Fombrun, C. and Van Riel, C. (2003), Fame and Fortune: How Successful Companies Build Winning Reputations, FT Prentice Hall, Upper Saddle River, NJ.

$\mathrm{Gu}, \mathrm{F}$. and Lev, B. (2011), "Intangible assets: measurement, drivers, and usefulness", in Gu, F. and Lev, B. (Eds), Managing Knowledge Assets and Business Value Creation in Organizations: Measures and Dynamics, IGI Global, pp. 110-124.

Haustein, E., Lorson, P.C., Caperchione, E. and Brusca, I. (2019), “The quest for users' needs in public sector budgeting and reporting", Journal of Public Budgeting, Accounting and Financial Management, Vol. 31 No. 4, pp. 473-477. 
Hines, R. (1988), "Financial accounting: in communicating reality, we construct reality", Accounting, Organizations and Society, Vol. 13 No. 3, pp. 251-261.

Jensen, M. and Roy, A. (2008), "Staging exchange partner choices: when do status and reputation matter?", Academy of Management Journal, Vol. 51 No. 3, pp. 495-516.

Johnsen, A., Reichborn-Kjennerud, K., Carrington, T., Jeppesen, K., Taro, K. and Vakkuri, J. (2019), "Supreme audit institutions in a high-impact context: a comparative analysis of performance audit in four Nordic countries", Financial Accountability and Management, Vol. 35 No. 2, pp. 158-181.

Jordan, S., Jørgensen, L. and Mitterhofer, H. (2013), "Performing risk and the project: risk maps as mediating instruments", Management Accounting Research, Vol. 24 No. 2, pp. 156-174.

Källström, L. (2019), “A good place to live': rethinking residents' place satisfaction and the role of cocreation”, Dissertation, Lund Studies in Economics and Management, Lund.

Kihn, L.A. (2010), "Performance outcomes in empirical management accounting research: recent developments and implications for future research", International Journal of Productivity and Performance Management, Vol. 59 No. 5, pp. 468-492.

Köhler, K. and Hoffmann, C. (2018), "Integrated reporting. Bridging investor relations and strategic management", in Laskin, A. (Ed.), The Handbook of Financial Communication and Investor Relations, Wiley-Blackwell, Hoboken, pp. 209-219.

Lange, D., Lee, P. and Dai, Y. (2011), "Organizational reputation: a review”, Journal of Management, Vol. 37 No. 1, pp. 153-184.

Lapsley, I. (2008), "The NPM agenda: back to the future”, Financial Accountability and Management, Vol. 22 No. 1, pp. 77-96.

Lapsley, I. (2009), "New public management: the cruellest invention of the human spirit?", Abacus, Vol. 45 No. 1, pp. 1-21.

Laskin, A. (2018), "Investor relations and financial communication. The evolution of the profession", in Laskin, A. (Ed.), The Handbook of Financial Communication and Investor Relations, WileyBlackwell, Hoboken, pp. 3-22.

Lev, B. (2019), "Ending the accounting-for-intangibles status quo", European Accounting Review, Vol. 28 No. 4, pp. 713-736.

Lie, E. and Lie, H. (2002), "Multiples used to estimate corporate value", Financial Analysts Journal, Vol. 58 No. 2, pp. $44-54$.

Luoma-aho, V. (2007), "Neutral reputation and public sector organizations", Corporate Reputation Review, Vol. 10 No. 2, pp. 124-143.

Luoma-aho, V. (2008), "Sector reputation and public organisations", International Journal of Public Sector Management, Vol. 21 No. 5, pp. 446-467.

Luoma-aho, V. (2015), "Understanding stakeholder engagement: faith-holders, hateholders and fakeholders", RJ-IPR: Research Journal of the Institute for Public Relations, Vol. 2 No. 1, pp. 1-28.

Luoma-aho, V. and Mäkikangas, M. (2014), "Do public sector mergers (re) shape reputation?", International Journal of Public Sector Management, Vol. 27 No. 1, pp. 39-52.

Meyer, J. (1996), "Otherhood: the promulgation and transmission of ideas in the modern organizational environment", in Czarniawska, B. and Sevón, G. (Eds), Translating Organizational Change, De Gruyter, Berlin, pp. 241-252.

Meyer, J. and Scott, W. (1983), "Centralization and the legitimacy problems of local government", in Meyer, J. and Scott, W. (Eds), Organizational Environments. Ritual and Rationality, Sage, Beverly Hills, CA, pp. 199-215.

Olkkonen, L. and Luoma-aho, V. (2015), "Broadening the concept of expectations in public relations", Journal of Public Relations Research, Vol. 27 No. 1, pp. 81-99.

Olson, O., Humphrey, C. and Guthrie, J. (2001), "Caught in an evaluatory trap: a dilemma for public services under NPFM”, European Accounting Review, Vol. 10 No. 3, pp. 505-522.
Reputation in Finnish public organizations 
JPBAFM 33,4

502

Overman, S., Busuioc, M. and Wood, M. (2019), “A multidimensional reputation barometer for public agencies: a validated instrument”, Public Administration Review, Vol. 81 No. 3, pp. 415-425.

Pina, V., Torres, L. and Royo, S. (2009), "E-government evolution in EU local governments: a comparative perspective", Online Information Review, Vol. 33 No. 6, pp. 1137-1168.

Power, M. (2000), "The audit society - second thoughts", International Journal of Auditing, Vol. 4 No. 1, pp. 111-119.

Power, M. (2001), "Imagining, measuring and managing intangibles”, Accounting, Organizations and Society, Vol. 7 No. 26, pp. 691-693.

Quattrone, P. (2016), "Management accounting goes digital: will the move make it wiser?", Management Accounting Research, Vol. 31, pp. 118-122.

Rautiainen, A., Urquía-Grande, E. and Muñoz-Colomina, C. (2017), "Institutional logics in police performance indicator development: a comparative case study of Spain and Finland", European Accounting Review, Vol. 26 No. 2, pp. 165-191.

Rousseau, D., Sitkin, S., Burt, R. and Camerer, C. (1998), "Not so different after all: a cross-discipline view of trust", Academy of Management Review, Vol. 23 No. 3, pp. 393-404.

Stenka, R. and Jaworska, S. (2019), "The use of made-up users", Accounting, Organizations and Society, Vol. 78, pp. 1-17.

Suddaby, R., Saxton, G. and Gunz, S. (2015), "Twittering change: the institutional work of domain change in accounting expertise", Accounting, Organizations and Society, Vol. 45, pp. 52-68.

Sztompka, P. (2000), "Cultural trauma: the other face of social change", European Journal of Social Theory, Vol. 3 No. 4, pp. 449-466.

Tyler, T. (2006), Why People Obey the Law, Princeton University Press, Princeton, NJ.

van Helden, J. and Reichard, C. (2019), "Making sense of the users of public sector accounting information and their needs", Journal of Public Budgeting, Accounting and Financial Management, Vol. 31 No. 4, pp. 478-495.

Wæraas, A. (2014), "Understanding organizational reputation in a public sector context", in Wæraas, A. and Maor, M. (Eds), Organizational Reputation in the Public Sector, Routledge, pp. 15-28.

Wæraas, A. and Byrkjeflot, H. (2012), "Public sector organizations and reputation management: five problems", International Public Management Journal, Vol. 15 No. 2, pp. 186-206.

Wallin Andreassen, T. (1994), "Satisfaction, loyalty and reputation as indicators of customer orientation in the public sector", International Journal of Public Sector Management, Vol. 7 No. 2, pp. 16-34.

Xun, J. and Guo, B. (2017), “Twitter as customer's eWOM: an empirical study on their impact on firm financial performance", Internet Research, Vol. 27 No. 5, pp. 1014-1038. 


\section{Appendices}

\section{Appendix 1}

\begin{tabular}{|c|c|c|c|c|c|c|c|c|}
\hline \multicolumn{2}{|c|}{ Coefficients } & \multicolumn{2}{|c|}{$\begin{array}{l}\text { Unstand. } \\
\text { coefficients }\end{array}$} & $\begin{array}{l}\text { Std. } \\
\text { coefficients }\end{array}$ & $t$ & Sig & \\
\hline 1 & (Constant) & 5.043 & 0.138 & & 36.544 & 0.000 & & \\
\hline & $\begin{array}{l}\text { Does not meet-meets } \\
\text { expectations }\end{array}$ & 0.837 & 0.035 & 0.715 & 23.685 & 0.000 & 1.000 & 1.000 \\
\hline 2 & (Constant) & 4.214 & 0.136 & & 30.914 & 0.000 & & \\
\hline & $\begin{array}{l}\text { Does not meet-meets } \\
\text { expectations }\end{array}$ & 0.559 & 0.038 & 0.478 & 14.901 & 0.000 & 0.675 & 1.481 \\
\hline & $\begin{array}{l}\text { Noncooperative-- } \\
\text { cooperative }\end{array}$ & 0.480 & 0.037 & 0.417 & 12.993 & 0.000 & 0.675 & 1.481 \\
\hline 3 & (Constant) & 3.736 & 0.139 & & 26.841 & 0.000 & & \\
\hline & $\begin{array}{l}\text { Does not meet-meets } \\
\text { expectations }\end{array}$ & 0.397 & 0.040 & 0.339 & 9.966 & 0.000 & 0.526 & 1.900 \\
\hline & $\begin{array}{l}\text { Noncooperative-- } \\
\text { cooperative }\end{array}$ & 0.389 & 0.036 & 0.338 & 10.769 & 0.000 & 0.619 & 1.616 \\
\hline & $\begin{array}{l}\text { Poor quality-high } \\
\text { quality }\end{array}$ & 0.361 & 0.042 & 0.289 & 8.660 & 0.000 & 0.548 & 1.825 \\
\hline 4 & (Constant) & 3.682 & 0.132 & & 27.831 & 0.000 & & \\
\hline & $\begin{array}{l}\text { Does not meet-meets } \\
\text { expectations }\end{array}$ & 0.339 & 0.039 & 0.289 & 8.773 & 0.000 & 0.506 & 1.977 \\
\hline & $\begin{array}{l}\text { Noncooperative-- } \\
\text { cooperative }\end{array}$ & 0.327 & 0.035 & 0.284 & 9.272 & 0.000 & 0.586 & 1.705 \\
\hline & $\begin{array}{l}\text { Poor quality-high } \\
\text { quality }\end{array}$ & 0.327 & 0.040 & 0.262 & 8.216 & 0.000 & 0.541 & 1.848 \\
\hline & Slow-fast & 0.213 & 0.028 & 0.213 & 7.733 & 0.000 & 0.722 & 1.385 \\
\hline 5 & (Constant) & 3.623 & 0.128 & & 28.223 & 0.000 & & \\
\hline & $\begin{array}{l}\text { Does not meet-meets } \\
\text { expectations }\end{array}$ & 0.285 & 0.038 & 0.243 & 7.430 & 0.000 & 0.479 & 2.086 \\
\hline & $\begin{array}{l}\text { Noncooperative-- } \\
\text { cooperative }\end{array}$ & 0.282 & 0.035 & 0.245 & 8.082 & 0.000 & 0.560 & 1.784 \\
\hline & $\begin{array}{l}\text { Poor quality-high } \\
\text { quality }\end{array}$ & 0.271 & 0.040 & 0.216 & 6.822 & 0.000 & 0.511 & 1.956 \\
\hline & Slow-fast & 0.205 & 0.027 & 0.206 & 7.707 & 0.000 & 0.721 & 1.387 \\
\hline & $\begin{array}{l}\text { For own good-for } \\
\text { common good }\end{array}$ & 0.173 & 0.028 & 0.179 & 6.083 & 0.000 & 0.592 & 1.689 \\
\hline
\end{tabular}

Note(s): Dependent variable: school grade, a general grade of performance from 4 to 10 , where 10 is the best
Reputation in Finnish public organizations

503

\begin{tabular}{lcccccccr}
\hline Model & $R$ & $R$ square & Adj. $R$ sq & Std. $E$. of estim & $R$ sq. Change & $F$ chg & df1 & df2 \\
\hline 1 & 0.715 & 0.511 & 0.510 & 0.66540 & 0.511 & 560.994 & 1 & 536 \\
2 & 0.793 & 0.629 & 0.627 & 0.58068 & 0.117 & 168.805 & 1 & 535 \\
3 & 0.821 & 0.674 & 0.672 & 0.54427 & 0.046 & 74.989 & 1 & 534 \\
4 & 0.841 & 0.707 & 0.705 & 0.51657 & 0.033 & 59.802 & 1 & 533 \\
5 & 0.852 & 0.726 & 0.724 & 0.49996 & 0.019 & 37.007 & 1 & 532
\end{tabular}

Note(s): In model 5 the independent variables included are: does not meet expectations-meets expectations, noncooperative-cooperative, poor quality-high quality, slow-fast,and for own good-for common good Dependent variable: school grade (general grade for operations given by the survey respondents, indicating an overall view on reputation and organizational performance)

Table A2.

Regression analysis explaining the general grade of operations (main explanatory model and the $R$ squares) 


\section{JPBAFM}

33,4

$\mathbf{5 0 4}$

\section{Appendix 2}

Table A3.

Pearson correlations for the general school grade

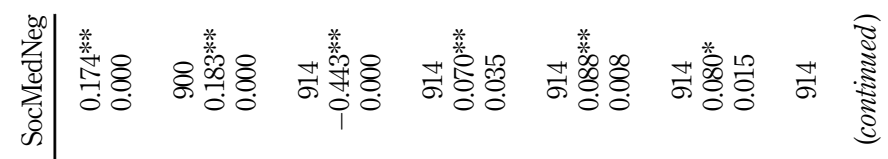

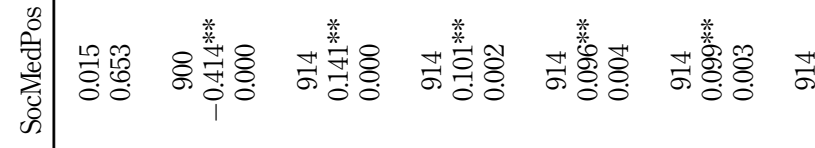

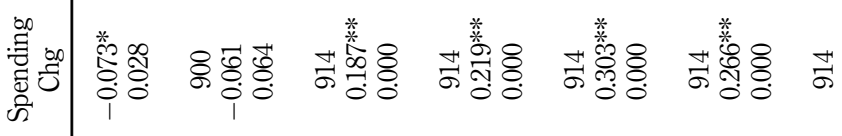

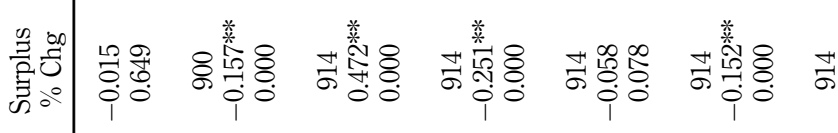

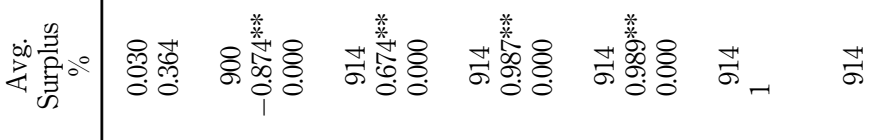

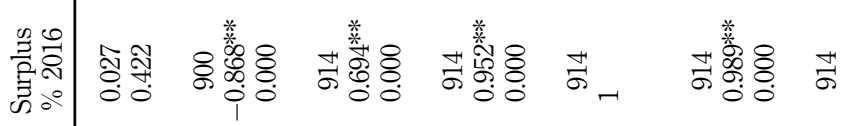

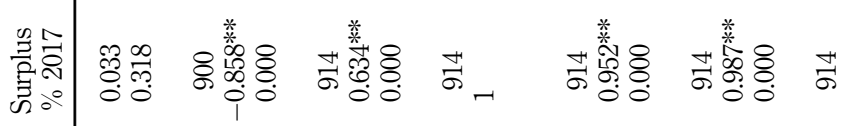

苟离

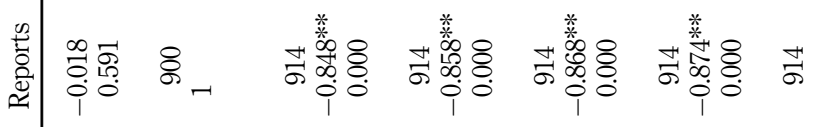

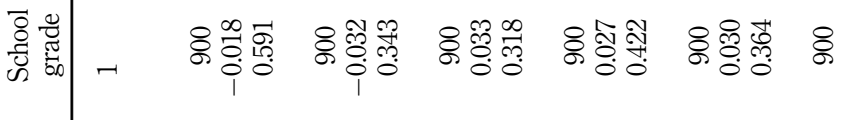

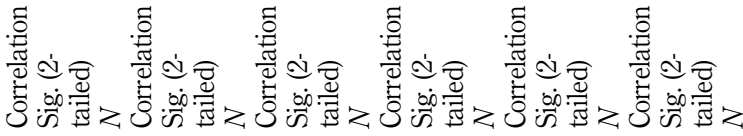


Reputation in

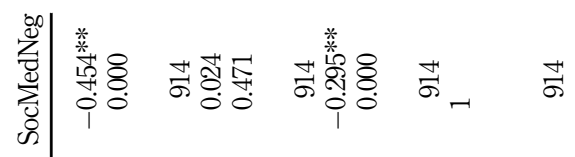

Finnish public

organizations

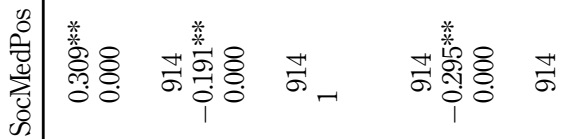

505

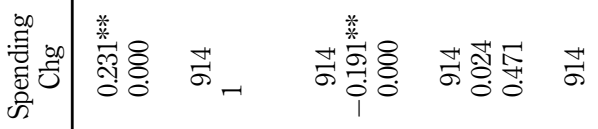

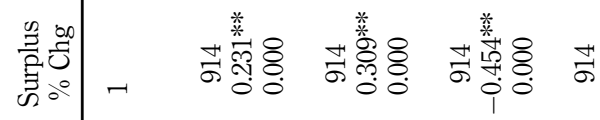

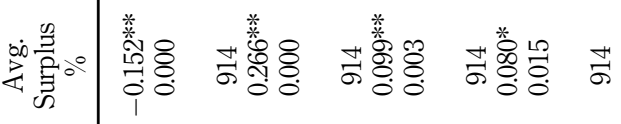

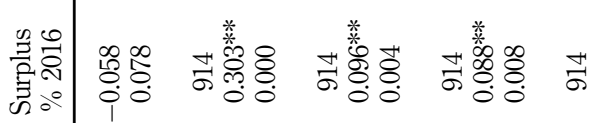

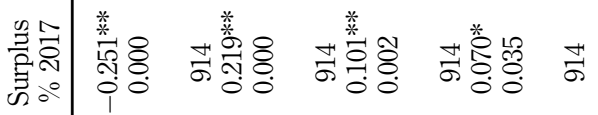

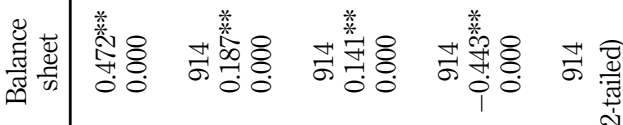

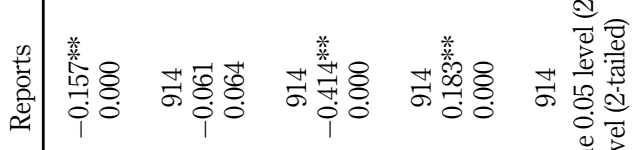

它芯

青壳

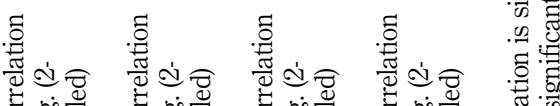

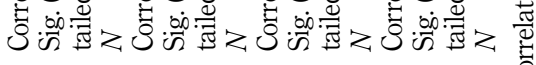

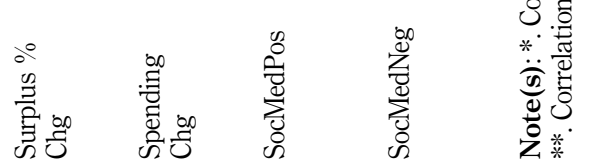

Table A3. 
JPBAFM

33,4

\begin{tabular}{|c|c|c|c|c|c|c|c|c|c|}
\hline & Model & $R$ & $R$ square & $\begin{array}{l}\text { Adjusted } R \\
\text { square }\end{array}$ & Std. E. of estim & $R$ sq. change & $F$ change & df1 & df2 \\
\hline 506 & $\begin{array}{l}1 \\
2\end{array}$ & $\begin{array}{l}0.771 \\
0.999\end{array}$ & $\begin{array}{l}0.594 \\
0.998\end{array}$ & $\begin{array}{l}0.593 \\
0.998\end{array}$ & $\begin{array}{l}0.60715 \\
0.04138\end{array}$ & $\begin{array}{l}0.594 \\
0.404\end{array}$ & $\begin{array}{r}789.117 \\
115524.190\end{array}$ & $\begin{array}{l}1 \\
1\end{array}$ & $\begin{array}{l}539 \\
538\end{array}$ \\
\hline
\end{tabular}

Note(s): In model 2, the variables included are: balance sheet and surplus percent 2017

Dependent variable: reporting quality grade

Coefficients $^{\mathrm{a}}$

\begin{tabular}{|c|c|c|c|c|c|c|c|c|}
\hline \multirow{2}{*}{\multicolumn{2}{|c|}{ Model }} & \multicolumn{2}{|c|}{ Unstand. coefficients } & \multirow{2}{*}{$\begin{array}{l}\text { Std. coefficients } \\
\text { Beta }\end{array}$} & & \multirow[b]{2}{*}{ Sig } & \multicolumn{2}{|c|}{ Collinearity stats } \\
\hline & & B & Std. error & & & & Tolerance & VIF \\
\hline & (Constant) & 9.033 & 0.038 & & 239.869 & 0.000 & & \\
\hline & Balance sheet & $-2.864 \mathrm{E}-8$ & 0.000 & -0.771 & -28.091 & 0.000 & 1.000 & 1.000 \\
\hline \multirow[t]{3}{*}{2} & (Constan & & 0.003 & & 2902.433 & 0.000 & & \\
\hline & Balance sheet & $-2.810 \mathrm{E}-8$ & 0.000 & -0.756 & -404.354 & 0.000 & 0.999 & 1.001 \\
\hline & Surplus \% 2017 & -2.356 & 0.007 & -0.636 & -339.888 & 0.000 & 0.999 & 1.001 \\
\hline
\end{tabular}

Table A4. $\quad$ Note(s): ${ }^{a}$ Dependent variable: reporting (quality grade)

Regression analysis of Details of the data that support the findings of this study are available on request from the corresponding reporting quality

\section{Appendix 4}

Pattern matrix ${ }^{\mathrm{a}}$

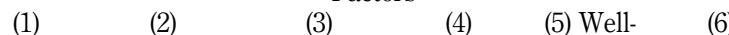

Trust Authority Efficiency esteem known Reach

Unfair-fair

Unethical-ethical

0.884

Irresponsible-responsible

0.858

0.852

Untrustworthy-trustworthy

0.810

For own good-for common good

0.776

Partial-neutral

0.770

Low expertise-high expertise

Does not act according to clear

0.539

principles-acts according to clear

0.438

0.076

esteen

known

$-0.008$

$-0.038$

0.076

$-0.138$

$\begin{array}{lr}-0.215 & -0.008 \\ -0.144 & 0.018\end{array}$

$-0.160$

0.023

0.081

$-0.094$

0.108

0.066

$-0.001$

0.040

0.016

principles

Useless-useful

0.133

0.016

0.013

$-0.043$

$\begin{array}{rr}-0.086 & 0.123\end{array}$

0.096

$-0.029$

0.009

$-0.089$

$-0.198$

Poor quality-high quality

$-0.179$

$-0.059$

0.314

0.066

$-0.152$

0.383

$-0.086$

$-0.029$

Insignificant research-significant

0.422

$-0.019$

0.032

0.026

0.002

0.048

0.213

research

Dictatorial-engaged in

0.378

$-0.025$

0.087

0.316

0.391

$-0.010$

0.301

$-0.036$

0.202

0.028

0.234

0.225

0.931

$-0.240$

0.063

$-0.233$

$-0.233$

conversation

Bureaucratic-flexible

Distant-humane

$-0.031$

0.838

0.099

0.016

$-0.283$

0.006

Static-dynamic

$-0.038$

0.733

$-0.010$

$-0.102$

0.141

0.071

0.725

0.346

0.038

$-0.095$

0.084

$-0.121$

0.224

Outdated-modern

Table A5.
Rotated pattern matrix

(Principal axis

0.173

0.653

0.175

$-0.060$

$-0.025$

$-0.144$

$-0.014$

0.602

0.037

$-0.112$

$-0.130$

$0.029 \quad 0.095$

Closed-open

0.250

0.052 
Pattern matrix ${ }^{\mathrm{a}}$

\begin{tabular}{|c|c|c|c|c|c|c|}
\hline & \multicolumn{6}{|c|}{ Factors } \\
\hline & $\begin{array}{l}(1) \\
\text { Trust }\end{array}$ & $\begin{array}{c}(2) \\
\text { Authority }\end{array}$ & $\begin{array}{c}(3) \\
\text { Efficiency }\end{array}$ & $\begin{array}{c}(4) \\
\text { esteem }\end{array}$ & $\begin{array}{l}\text { (5) Well- } \\
\text { known }\end{array}$ & $\begin{array}{c}(6) \\
\text { Reach }\end{array}$ \\
\hline $\begin{array}{l}\text { Does not find out customer needs- } \\
\text { finds out customer needs }\end{array}$ & 0.176 & 0.449 & 0.039 & -0.060 & 0.129 & 0.174 \\
\hline Noncooperative-cooperative & 0.215 & 0.430 & -0.073 & 0.062 & 0.174 & 0.049 \\
\hline $\begin{array}{l}\text { Not customer-oriented-customer- } \\
\text { oriented }\end{array}$ & 0.110 & 0.397 & 0.088 & -0.170 & 0.206 & 0.126 \\
\hline Inefficien -efficient & 0.048 & 0.027 & 0.817 & -0.178 & 0.106 & -0.006 \\
\hline Slow-fast & -0.086 & 0.273 & 0.783 & -0.114 & -0.182 & 0.098 \\
\hline Fractured-coherent & 0.114 & 0.052 & 0.625 & -0.062 & -0.016 & 0.030 \\
\hline $\begin{array}{l}\text { Does not keep to schedule-keeps to } \\
\text { schedule }\end{array}$ & 0.218 & 0.006 & 0.559 & 0.086 & -0.243 & 0.142 \\
\hline Poor leadership-good leadership & 0.145 & -0.009 & 0.534 & 0.124 & -0.023 & -0.030 \\
\hline $\begin{array}{l}\text { Communicates its aims unclearly- } \\
\text { communicates its aims clearly }\end{array}$ & 0.013 & -0.062 & 0.510 & 0.168 & 0.050 & 0.157 \\
\hline $\begin{array}{l}\text { Produces difficult-to-use } \\
\text { information-produces easy-to-use } \\
\text { information }\end{array}$ & 0.055 & 0.036 & 0.407 & -0.012 & 0.229 & 0.030 \\
\hline $\begin{array}{l}\text { Not under constant development- } \\
\text { under constant development }\end{array}$ & 0.067 & 0.264 & 0.272 & 0.143 & 0.194 & -0.204 \\
\hline $\begin{array}{l}\text { Not internationally esteemed- } \\
\text { internationally esteemed }\end{array}$ & 0.016 & -0.081 & -0.112 & 0.741 & -0.054 & 0.126 \\
\hline $\begin{array}{l}\text { Lags behind in its field-a trend- } \\
\text { setter in its field }\end{array}$ & -0.019 & 0.108 & 0.085 & 0.640 & 0.047 & -0.033 \\
\hline Not esteemed-esteemed & 0.112 & 0.126 & -0.214 & 0.530 & 0.116 & 0.111 \\
\hline Reactive-proactive & -0.035 & 0.308 & 0.217 & 0.406 & -0.171 & 0.065 \\
\hline Poor employer-good employer & -0.026 & 0.082 & 0.199 & 0.378 & 0.118 & -0.041 \\
\hline $\begin{array}{l}\text { Poorly motivated employees- } \\
\text { motivated employees }\end{array}$ & 0.300 & -0.102 & 0.210 & 0.377 & -0.019 & 0.022 \\
\hline Unknown-well-known & -0.103 & -0.118 & -0.062 & 0.013 & 0.687 & 0.052 \\
\hline $\begin{array}{l}\text { Does not meet expectations -meets } \\
\text { expectations }\end{array}$ & 0.097 & 0.124 & 0.045 & 0.129 & 0.355 & 0.210 \\
\hline Passive-active & -0.123 & 0.245 & 0.240 & 0.085 & 0.278 & 0.137 \\
\hline Inaccessible-accessible & -0.009 & 0.103 & 0.161 & 0.085 & -0.032 & 0.592 \\
\hline States the contact person & -0.132 & 0.110 & 0.077 & 0.115 & 0.105 & 0.566 \\
\hline
\end{tabular}

Reputation in Finnish public organizations

unclearly-states the contact person

clearly

Note(s): Extraction method: principal axis factoring

Rotation method: promax with Kaiser normalization

${ }^{a}$ Rotation converged in 7 iterations

Cronbach's alpha was 0.936

Kaiser-Mayer-Olkin test of sampling adequacy (0.971) and Bartlett's test for sphericity (sig. $<0.000$ ) were ok

Table A5. 
1. Please state in a few words or adjectives what first comes to your mind about the main study organisation

Next I would like to ask you to rate the main study organisation through various statements. Please consider each statement as to how well it describes it. Then circle the number that best represents your opinion.

2. on co-operative

3. not customer orientated

4. partial

5. close

6. for its own good

7. inefficient

8. irresponsible

9. unethical

10. not under constant development

11. unknown

12. not esteemed

13. active

14. finds out customer needs

15. state clearly the contact persons

16. high quality

17. accessible

18. useful

19. meets expectations

20. acts according to clear principles

21. fair

22. poor leadership

23. low expertise

24. untrustworthy

25 . reactive

26. static

27. bureaueratic

28 . not internationally esteemed

29. distant

30. dictatorial

31. insignificant research

32. outdated

33 . poorly motivated employees

34. slow

35. does not keep to schedule

36 . communicates its aims unclearly

37. poor employer

38. fractured

39. unable to listen

40. lags behind in its field

41. part of the ministry's entity

$\begin{array}{lllll}1 & 2 & 3 & 4 & 5 \\ 1 & 2 & 3 & 4 & 5 \\ 1 & 2 & 3 & 4 & 5 \\ 1 & 2 & 3 & 4 & 5 \\ 1 & 2 & 3 & 4 & 5 \\ 1 & 2 & 3 & 4 & 5 \\ 1 & 2 & 3 & 4 & 5 \\ 1 & 2 & 3 & 4 & 5 \\ 1 & 2 & 3 & 4 & 5 \\ 1 & 2 & 3 & 4 & 5 \\ 1 & 2 & 3 & 4 & 5\end{array}$

$\begin{array}{lllll}1 & 2 & 3 & 4 & 5\end{array}$

$\begin{array}{lllll}1 & 2 & 3 & 4 & 5\end{array}$

$\begin{array}{lllll}1 & 2 & 3 & 4 & 5\end{array}$

$\begin{array}{lllll}1 & 2 & 3 & 4 & 5\end{array}$

$\begin{array}{lllll}1 & 2 & 3 & 4 & 5\end{array}$

$\begin{array}{lllll}1 & 2 & 3 & 4 & 5\end{array}$

$\begin{array}{lllll}1 & 2 & 3 & 4 & 5\end{array}$

$\begin{array}{lllll}1 & 2 & 3 & 4 & 5\end{array}$

$\begin{array}{lllll}1 & 2 & 3 & 4 & 5\end{array}$

$\begin{array}{lllll}1 & 2 & 3 & 4 & 5\end{array}$

$\begin{array}{lllll}1 & 2 & 3 & 4 & 5\end{array}$

$\begin{array}{lllll}1 & 2 & 3 & 4 & 5\end{array}$

$\begin{array}{lllll}1 & 2 & 3 & 4 & 5\end{array}$

$\begin{array}{lllll}1 & 2 & 3 & 4 & 5\end{array}$

$\begin{array}{lllll}1 & 2 & 3 & 4 & 5\end{array}$

$\begin{array}{lllll}1 & 2 & 3 & 4 & 5\end{array}$

$\begin{array}{lllll}1 & 2 & 3 & 4 & 5\end{array}$

$\begin{array}{lllll}1 & 2 & 3 & 4 & 5\end{array}$

$\begin{array}{lllll}1 & 2 & 3 & 4 & 5\end{array}$

$\begin{array}{lllll}1 & 2 & 3 & 4 & 5\end{array}$

$\begin{array}{lllll}1 & 2 & 3 & 4 & 5\end{array}$

$\begin{array}{lllll}1 & 2 & 3 & 4 & 5\end{array}$

$\begin{array}{lllll}1 & 2 & 3 & 4 & 5\end{array}$

$\begin{array}{lllll}1 & 2 & 3 & 4 & 5\end{array}$

$\begin{array}{lllll}1 & 2 & 3 & 4 & 5\end{array}$

$\begin{array}{lllll}1 & 2 & 3 & 4 & 5\end{array}$

$\begin{array}{lllll}1 & 2 & 3 & 4 & 5\end{array}$

$\begin{array}{lllll}1 & 2 & 3 & 4 & 5\end{array}$

$\begin{array}{lllll}1 & 2 & 3 & 4 & 5\end{array}$ co-operative

customer orientated

neutral

open

for the common good

efficient

responsible

ethical

under constant development

well-known

esteemed

passive

does not finds out customer needs state unclearly the contact persons poor quality

inaccessible

useless

does not meets expectations

does not acts according to clear principles unfair

good leadership

high expertise

trustworthy

proactive

dynamic

flexible

internationally esteemed humane

engaged in conversation

significant research

modern

highly motivated employees

fast

keeps to schedule

communicates its aims clearly

good employer

coherent

able to listen

a trend-setter in its field

independent

42. What school grade would you give to the main study organisation's operation's? (scale 4-10)?

Next you are given a chance to freely write about the case organisation:

43. What experiences do you have of dealing with the case organisation? 


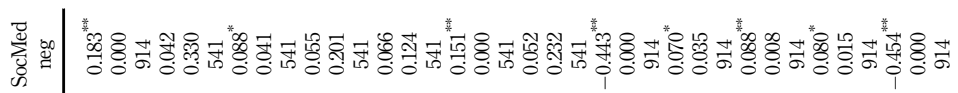

荧

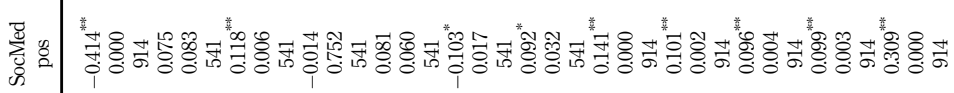

热

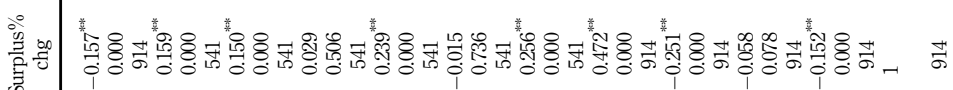

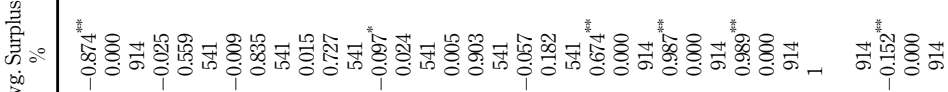
妿

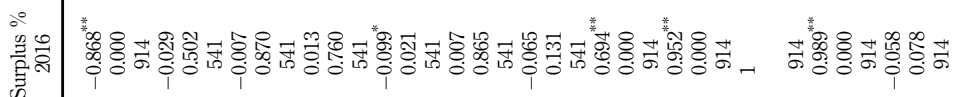

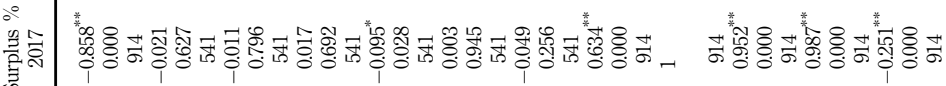

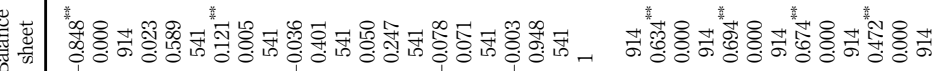

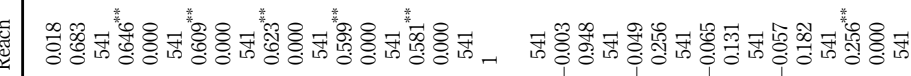

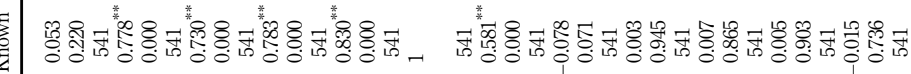

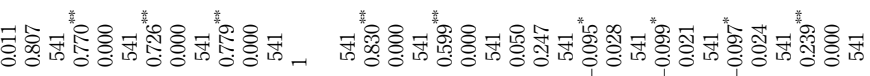

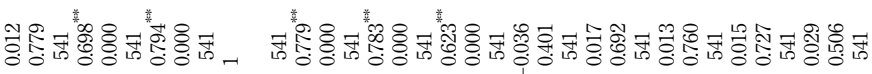

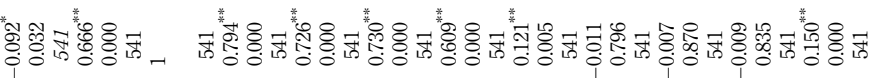

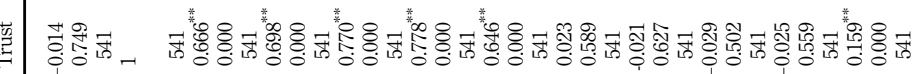

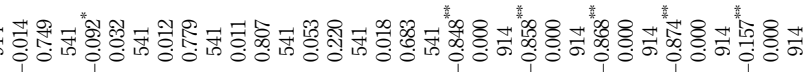

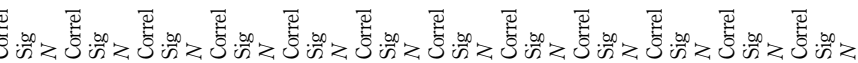

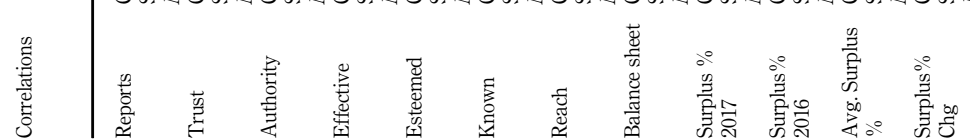

Table A6. Pearson correlations between reports, factors and financial items (with 2-tailed significance) 


\section{JPBAFM \\ 33,4}

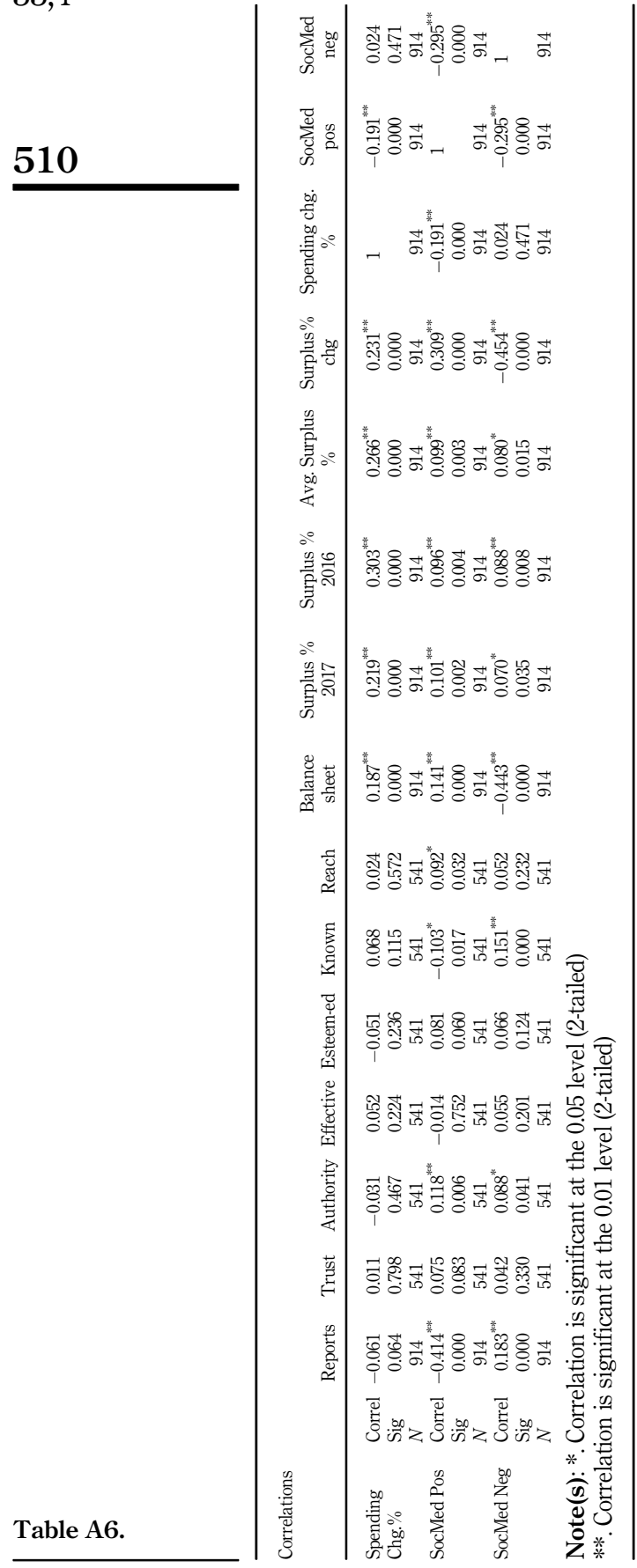




\section{Appendix 7}

\begin{tabular}{|c|c|c|c|c|c|c|c|c|c|c|}
\hline Model & ummary $^{\mathrm{b}}$ & $\begin{array}{c}R \\
\text { square }\end{array}$ & $\begin{array}{l}\text { Adj. } R \\
\text { square }\end{array}$ & $\begin{array}{c}\text { Std. error } \\
\text { of } \\
\text { estimate }\end{array}$ & $\begin{array}{l}R \text { sq. } \\
\text { change }\end{array}$ & $\begin{array}{c}\text { Chang } \\
F \\
\text { change }\end{array}$ & statist & ics & $\begin{array}{l}\text { Sig. } F \\
\text { change }\end{array}$ & $\begin{array}{l}\text { Durbin- } \\
\text { Watson } \\
\end{array}$ \\
\hline 1 & $0.868^{\mathrm{a}}$ & 0.754 & 0.749 & 0.47615 & 0.754 & 161.531 & 10 & 527 & 0.000 & 2.102 \\
\hline \multirow{2}{*}{\multicolumn{2}{|c|}{$\begin{array}{l}\text { Coefficients } \\
\text { Model } 1 \\
\end{array}$}} & \multicolumn{3}{|c|}{ Unstand. Coeff } & \multicolumn{4}{|c|}{ Standardized coefficients } & \multicolumn{2}{|c|}{ Collinearity statistics } \\
\hline & & $B$ & & td. error & Beta & $t$ & Sig & & Tolerance & VIF \\
\hline \multicolumn{2}{|c|}{ (Constant) } & 7.96 & & 0.242 & & 32.834 & 0.00 & & & \\
\hline \multicolumn{2}{|c|}{$f 1$ Ethical } & 0.22 & & 0.039 & 0.23 & 5.818 & 0.00 & & 0.3 & 3.337 \\
\hline \multicolumn{2}{|c|}{ f2 Modern } & 0.31 & & 0.039 & 0.324 & 8.194 & 0.00 & & 0.298 & 3.35 \\
\hline \multicolumn{2}{|c|}{ f3 Effective } & & & 0.044 & 0.115 & 2.571 & 0.01 & & 0.235 & 4.252 \\
\hline \multicolumn{2}{|c|}{ f4 Esteemed } & 0.02 & & 0.05 & 0.021 & 0.427 & $0.66 \varsigma$ & & 0.197 & 5.064 \\
\hline \multicolumn{2}{|c|}{ f5 Known } & 0.2 & & 0.053 & 0.23 & 4.546 & 0.00 & & 0.183 & 5.478 \\
\hline \multicolumn{2}{|c|}{$f 6$ Reach } & & & 0.035 & 0.029 & 0.891 & 0.373 & & 0.442 & 2.263 \\
\hline \multirow{2}{*}{\multicolumn{2}{|c|}{$\begin{array}{l}\text { Surplus \% Chg } \\
\text { Spending \% Chg }\end{array}$}} & 0.35 & & 0.104 & 0.124 & 3.387 & 0.001 & & 0.348 & 2.875 \\
\hline & & 1.6 & & 0.581 & 0.107 & 2.86 & 0.004 & & 0.333 & 3.007 \\
\hline \multicolumn{2}{|c|}{ Soc.med Neg } & & & 0.01 & 0.031 & 1.104 & 0.27 & & 0.595 & 1.681 \\
\hline \multicolumn{2}{|c|}{ Reports } & 0.03 & & 0.023 & 0.038 & 1.668 & 0.096 & & 0.881 & 1.135 \\
\hline
\end{tabular}

Note(s): ${ }^{a}$ Predictors: (Constant), Reports, $f 1$ Ethical, Surplus \% Chg, Soc.med Neg, $f 6$ Reach, $f 2$ Modern, Spending \% Chg, $f 4$ Esteemed, $f 3$ Effective, $f 5$ Known

bDependent variable: School grade. Regression method "Enter", i.e. all variables are added to the model Dependent variable: school grade
Reputation in Finnish public organizations

Table A7.

Regression analysis of performance and reputation

\section{Corresponding author}

Antti Rautiainen can be contacted at: antti.i.rautiainen@jyu.fi

For instructions on how to order reprints of this article, please visit our website:

www.emeraldgrouppublishing.com/licensing/reprints.htm

Or contact us for further details: permissions@emeraldinsight.com 